\title{
Expression of Stromal Derived Factor-1 is Upregulated in Macrophages during Thymic Regeneration in Adult Rat
}

\author{
Hyun-Joo Park ${ }^{1,4}$, Jong-Gab Kim², ${ }^{2,45}$, Sik Yoon ${ }^{3,4,5}$, Moon-Kyoung Bae ${ }^{1}$ and Soo-Kyung Bae ${ }^{2,4,5}$ \\ ${ }^{1}$ Department of Oral Physiology, School of Dentistry, ${ }^{2}$ Department of Physiology, ${ }^{3}$ Department of Anatomy, School of Medicine, \\ ${ }^{4}$ Medical Research Center for Ischemic Tissue Regeneration, Pusan National University, Yangsan, 626-770, South Korea \\ ${ }^{5}$ Pusan National University Medical Science Education Center (BK21 Program), Pusan National University, Yangsan, 626-770, South Korea
}

Received July 2, 2009 / Accepted July 14, 2009

\begin{abstract}
Stromal derived factor-1 (SDF-1 or CXCL12), one of the CXC chemokines, is widely expressed in many tissues, including the thymus. The thymus can regenerate to its normal mass within 14 days after acute involution induced by cyclophosphamide (CY) in adult rats. Despite the established role of SDF-1 signaling in the development of T and B lymphocytes in the thymus, it has not yet been associated with the regeneration of the adult thymus. The purpose of this study was to investigate whether SDF-1, which is expressed in thymic stromal cells, is modulated during thymic regeneration in adult rats. Here, we showed that SDF-1 mRNAs were expressed in high levels in the thymocyte and thymic stromal cells at day 7 of the CY model. SDF-1 protein was shown to be present at the cortex-medulla junction, paraseptum and within the thymic medulla. Double-immunofluorescence for SDF-1 and ED-1 showed that strong SDF-1 expression was detected in the macrophages of the medulla region displaying immunoreactivity for ED-1 during thymus regeneration. Taken together, our results demonstrated that SDF-1 expression increased in regenerating thymic macrophages, suggesting the roles of SDF-1 as a chemo-attractant for damaged cells produced in the process of thymic regeneration after acute involution induced by $\mathrm{CY}$.
\end{abstract}

Key words : SDF-1, macrophage, thymic regeneration

\section{Introduction}

The thymus has a central role in the immune system, providing a specialized microenvironment for $\mathrm{T}$ cell maturation [10]. Once precursor cells colonize the thymus, the developing $\mathrm{T}$ cells move from the subcapsular, through the cortex into the central medulla, and they receive signals for survival, proliferation, receptor gene rearrangement, positive selection and negative selection, molecular and functional maturation, and migration [14]. Thymic stroma provides a specialized microenvironment for the development of $\mathrm{T}$ cells, and consists of epithelial cells, macrophages, dendritic cells and fibroblasts, all of which play specific roles at different stages of $\mathrm{T}$ cell differentiation [1]. With advancing age or under any of stressful conditions, the gradual loss of thymic structure and function causes a decline in thymic output and subsequent losses of naïve $\mathrm{T}$ cells $[16,17]$. Attempts to define the molecular mechanism of thymic involution have so far relied on investigating the changing levels of expression of molecules, such as cyto-

*Corresponding author

Tel : +82-51-510-8074, Fax : +82-51-510-8076

E-mail : skbae@pusan.ac.kr kines, growth factors, neuropeptides and their receptors, with aging. It was previously demonstrated that acute thymic involution, induced in experimental animals, is followed by intensive regeneration after the removal of the causative stimuli $[9,19]$. However, the molecular mechanisms underlying thymus regeneration are still largely unknown. Thus, it is a matter of considerable importance to understand the mechanism of thymus regeneration and develop methods of normalizing or improving host immunity when immune function is depressed due to thymic involution.

Chemokines, small pro-inflammatory chemoattractant cytokines, and their receptors have been discovered as essential and selective mediators in leukocyte migration to inflammatory sites [18]. Stromal derived factor-1 (SDF-1), also called CXCL12, a member of the chemokine CXC subfamily, was first identified as a pre-B-cell growth factor and has been known as a chemotactic factor for $\mathrm{T}$ cell, monocytes, dendritic cells, and hematopoietic progenitor cells $[8,11]$.

SDF-1 exerts its effects via the binding to CXCR4, a receptor member of the G-protein-coupled receptor superfamily that is expressed constitutively in a wide variety of 
normal tissue, including lymphatic tissues, brain, spleen, stomach, small intestine, and thymus [11]. Recently, it was also reported that SDF-1/CXCR4 not only regulates the development of $\mathrm{T}$ and $\mathrm{B}$ lymphocytes but also contributes to the survival of lymphocytes and in the generation of memory $\mathrm{T}$ cells [6]. These observations strongly suggest that SDF-1/CXCR4 signaling has a functional role in thymus development. However, whether the SDF-1/CXCR4 signaling is also involved during thymic regeneration in adult rat is actually not known.

Thus, the aim of the present study was to characterize the expression pattern of SDF-1 on the thymic macrophage and to shed light on its role in thymus regeneration.

\section{Materials and Methods}

\section{Cell lines}

The generation, maintenance, and functional characterization of the mouse thymic subcapsular cortex or thymic nurse epithelial cells (427.1; SNEC), deep cortex or cortical reticular epithelial cells (1308.1; CREC), and medullary epithelial cells $(6.1 .7$; MEC) have been described by Faas et al [4]. These cell lines were cultured in DMEM (Gibco-BRL, Grand Island, NY, USA) containing 10\% FBS (FBS, GibcoBRL) and $2 \mathrm{mM}$ glutamine (Sigma), $100 \mathrm{U} / \mathrm{ml}$ penicillin (Gibco-BRL), and $100 \mu \mathrm{g} / \mathrm{ml}$ streptomycin (Gibco-BRL) at $37^{\circ} \mathrm{C}$ in $5 \% \mathrm{CO}_{2}$-enriched atmosphere.

\section{Experimental acute thymic involution and regeneration model}

Adult male-specific pathogen-free Sprague-Dawley rats were purchased from Dae Han Bio Link (Seoul, Korea). All rats were housed three to four per cage and maintained under a $12 \mathrm{hr}$ light/dark cycle at $24^{\circ} \mathrm{C}$ in a specific pathogen-free and humidity-controlled facility. Animals were provided with standard sterile food and water ad libitum, and were allowed to adjust to their environment for 1 week. Animals were used at 8-10 weeks of age, by being given a single intraperitoneal dose of cyclophosphamide (150 mg/kg body weight, Sigma, St. Louis, USA) in normal saline, and were sacrificed in groups of four at 3, 7 and 14 days after injection. Rats given the same amount of normal saline were used as controls. Animal care and all experimental procedures were conducted in accordance with the "Guide for Animal Experiments" edited by the Korean Academy of Medical Sciences.

\section{Thymocyte and thymic stromal cell isolation}

Two to three thymi were dissected from freshly killed rats and trimmed of fat and connective tissue. Small cuts (2-3 mm) were made into the capsules with a pair of razors, and thymi were gently agitated in $30 \mathrm{ml}$ of RPMI-1640 using a magnetic stirrer at $4^{\circ} \mathrm{C}$ for $40 \mathrm{~min}$. The resulting thymic fragments and supernatant were transferred into separate tubes. For the isolation of thymocytes, the supernatant was passed three times through $70 \mu \mathrm{m}$ mesh and centrifuged. The cell pellet was resuspended in $20 \mathrm{ml}$ of ACK lysis solution $\left(0.15 \mathrm{M} \mathrm{NH}_{4} \mathrm{Cl}, 1 \mathrm{mM} \mathrm{KHCO}, 0.1 \mathrm{mM}\right.$ $\mathrm{Na}_{2}$ EDTA) to remove red blood cells. The thymocytes suspension was washed three times with HBSS buffer. The thymocytes were resuspended in HBSS buffer, and viable cells were counted using the hemocytometer after trypan blue staining. For the isolation of thymic stromal cells, the thymic fragments were transferred into $5 \mathrm{ml}$ of RPMI-1640 containing $0.125 \%(\mathrm{w} / \mathrm{v})$ collagenase D and $0.1 \%(\mathrm{w} / \mathrm{v})$ DNAse I (both from Roche) and then incubated for $15 \mathrm{~min}$ with gentle shaking in a water bath at $37^{\circ} \mathrm{C}$. The thymic fragments in the enzyme mixtures were carefully dispersed with a Pasteur pipette several times, and the supernatant was removed after fragments had settled and was replaced with fresh enzyme mixture. Gentle mechanical agitation was provided using a $5 \mathrm{ml}$ syringe and $18 \mathrm{G}$ needle, then a $21 \mathrm{G}$ needle, followed by a $23 \mathrm{G}$ needle. Tissue fragments were allowed to settle, and the supernatant was discarded. This digestion process was repeated four more times until the tissue was fully digested. Cells liberated by the fourth, fifth, and sixth digests were saved, filtered through a 100 $\mu \mathrm{m}$ mesh to remove undigested particles, and washed with HBSS buffer. They were then resuspended in HBSS buffer, and viable cells were counted using the hemocytometer after trypan blue staining.

\section{Reverse transcriptase-polymerase chain reaction (RT-PCR) analysis}

Total RNA was isolated from each sample using easy-Blue reagent (Intron) following the manufacturer's protocol. Briefly, the samples were transferred to a tube containing $1 \mathrm{ml}$ of the RNA extraction solution. The homogenate was then chloroform extracted, isopropanol precipitated, ethanol washed, and resuspended in $30 \mu \mathrm{l}$ of distilled water. RNA concentration and purity were determined by absorbance at 260 and $280 \mathrm{~nm}$. First strand cDNA was obtained by reverse transcription (RT) using $3 \mu \mathrm{g}$ of total rat thymus RNA. The 
reaction was conducted in $20 \mu \mathrm{l}$ of buffer containing $0.5 \mu \mathrm{g}$ of Oligo (dT) ${ }_{12-18}$ primer (Gibco-BRL), $50 \mathrm{mM}$ Tris- $\mathrm{HCl}(\mathrm{pH}$ 8.3), $75 \mathrm{mM} \mathrm{KCl}, 3 \mathrm{mM} \mathrm{MgCl} 2,40 \mathrm{mM}$ DTT, $0.5 \mathrm{mM}$ deoxynucleotide triphosphate (dNTP) mixture (Gibco-BRL), 10 units RNase inhibitor (Gibco-BRL), and 200 units of MMLV reverse transcriptase (Gibco-BRL). After incubation at $37^{\circ} \mathrm{C}$ for $60 \mathrm{~min}$, the reaction was stopped by heating at $70^{\circ} \mathrm{C}$ for $15 \mathrm{~min}$. To remove the remaining RNA, $1 \mu \mathrm{l}$ of $E$. coli $\mathrm{RNase} \mathrm{H}(4 \mathrm{mg} / \mathrm{ml})$ was added to the reaction mixture and incubated at $37^{\circ} \mathrm{C}$ for $30 \mathrm{~min}$. The oligonucleotide primers for PCR were designed as follows: GAPDH, $5^{\prime}$-CAACT CCCTCAACATTGTCAGC- $3^{\prime}$ and 5'-GGGAGTTGCTGTTG AAGTCACA-3'; SDF-1 $\alpha, 5^{\prime}$-GATCCAAGAGTACCTGGACA $-3^{\prime}$ and $5^{\prime}$-GATGAGGAAGATGAGGATGA-3'; SDF-1 $\beta, 5^{\prime}$-A AGAGGCTCAAGATGTGAGA- $3^{\prime}$ and $5^{\prime}$-CTCAAAGAGAC AAACCTTGG-3'.

\section{Immunohistochemistry}

After cryosections, immunostaining was performed using the streptavidin-biotin complex $(\mathrm{ABC})$ method. In brief, sections were incubated for $20 \mathrm{~min}$ in a solution of phosphate-buffered saline (PBS) containing $0.3 \% \mathrm{H}_{2} \mathrm{O}_{2}$ to eliminate endogenous peroxidase activities. After washing in PBS, sections were incubated with $2 \%$ normal donkey serum (Vector Laboratories, Burlingame, CA). The excess solution was shaken off and sections were incubated for 16-18 hr at $4^{\circ} \mathrm{C}$ with an affinity-purified Rabbit polyclonal anti-SDF-1 antibody (sc-28876, diluted 1:100, Santa Cruz Biotechnology, Santa Cruz, CA). Following incubation with the primary antibody, sections were washed three times for $5 \mathrm{~min}$ with PBS and incubated for $2 \mathrm{hr}$ at room temperature with an $\mathrm{F}\left(\mathrm{ab}^{\prime}\right)_{2}$ fragment mouse anti-rabbit biotinylated antibody diluted 1:100 (Jackson ImmunoResearch Laboratories, West Grove, PA). They were then rinsed in PBS and incubated for $60 \mathrm{~min}$ at room temperature with an $A B C$ reagent (Vectastain Elite Kit; Vector Laboratories) according to the manufacturer's instructions. Sections were developed in $0.025 \% 3,3^{\prime}$-diaminobenzidine and $0.003 \%$ $\mathrm{H}_{2} \mathrm{O}_{2}$ medium under microscopic control at room temperature to visualize peroxidase activity. Sections were rinsed in distilled water, counterstained with Mayer's hematoxylin, and mounted in a xylene-based mounting medium (Entellan, Darmstadt, Germany). Slides were observed and photographed using an Olympus BX50 microscope. All photomicrographs were taken with an Olympus C-3030 digital camera.

\section{Double Immunofluorescence Staining}

Two-color double immunohistochemical analysis was performed in order to confirm whether the cells that express SDF-1 are macrophages. After the sections were rinsed in PBS and incubated with 2\% normal donkey serum for 60 $\mathrm{min}$, they were incubated with the first primary antibody (Rabbit polyclonal anti-SDF-1 antibody, sc-28876, Santa Cruz Biotechnology) for 16-18 hr at 4 . Following incubation with the primary antibody, the sections were incubated with an $\left.\mathrm{F}(\mathrm{ab})_{2}\right)_{2}$ fragment of donkey anti-rabbit Texas Red-conjugated antibody at a dilution of 1:100 (Jackson ImmunoResearch Laboratories). After the sections were rinsed in PBS, they were further incubated with the second primary antibody. For the second primary antibody, we used affinity-purified mouse anti-ED1 antibody (Jackson ImmunoResearch Lab.) at a dilution of 1:100 to identify for the reactivity with the macrophages of the rat thymus. The sections were incubated with an $\mathrm{F}\left(\mathrm{ab} \mathrm{b}^{\prime}\right)_{2}$ fragment of donkey anti-mouse FITC-conjugated antibody diluted 1:100 (Jackson ImmunoResearch Laboratories). The samples were examined under a fluorescence microscope (Axiphot, Zeiss).

\section{Results}

Upregulation of SDF-1 mRNA expression during thymic regeneration

To investigate the expression pattern of SDF-1 genes in regenerating thymus of adult rat, the levels of SDF- 1 alpha and beta mRNAs were analyzed by quantitative RT-PCR analysis. As shown in Fig. 1A, while the levels of SDF-1a mRNAs were slightly increased during thymic regeneration, the mRNA levels of SDF-1 $\beta$ were significantly elevated at 3 days, reached peak levels at 7 days after $\mathrm{CY}$ treatment in both thymocytes and thymic stromal cells, and then declined by 14 days. RT-PCR analysis of various cell lines showed that the thymic subcapsular cortex or thymic nurse epithelial cells (427.1; SNEC), the deep cortex or cortical reticular epithelial cells (1308.1; CREC), medullary epithelial cells (6.1.7; MEC), and D1 thymocytes expressed a very high level of SDF-1 $\beta$ mRNA, while the medullary interdigitating (IDC)-like cells (6.1.1; MDC) display little SDF-1 $\beta$ mRNA (Fig. 1B).

\footnotetext{
Upregulation of SDF-1 protein expression during thumic regeneration

We next verified the expression pattern of SDF-1 protein
} 
(A)
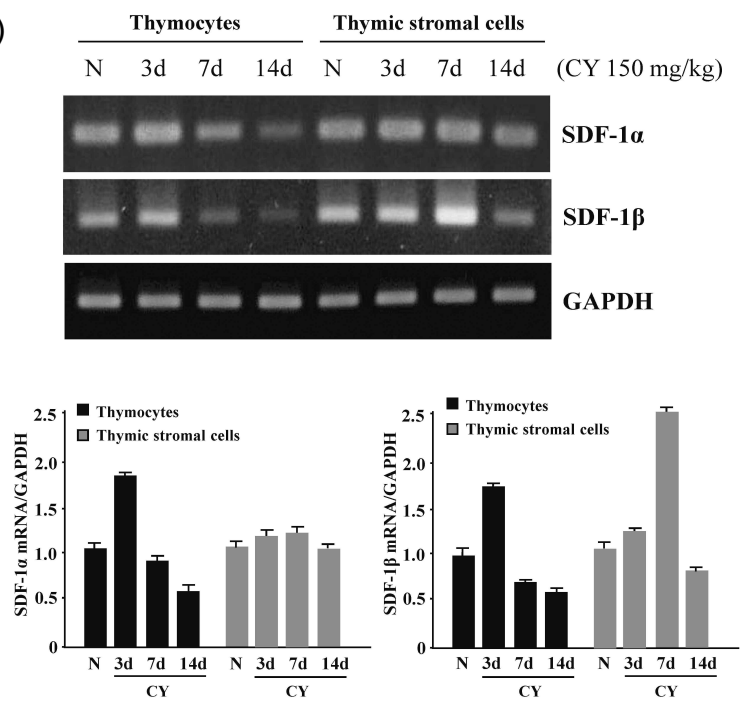

(B)

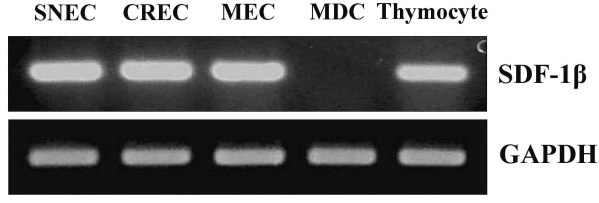

Fig. 1. Differential expression of SDF-1 family members in thymocytes and thymic stromal cells during thymic regeneration. (A) RT-PCR analysis of SDF-1 family and GAPDH mRNA expression in thymocytes and thymic stromal cells isolated from normal thymus $(\mathrm{N})$ and regenerating thymus at $3(3 \mathrm{~d}), 7$ (7d) and 14 (14d) days after cyclophosphamide (CY) treatment. (B) SDF-1 13 mRNA in the mouse epithelial cell line subcapsullar/ paraseptal epithelial cells (SNEC), cortical epithelial cells (CREC), medullary epithelial cells (MEC), medullary interdigitating (IDC)-like cells (MDC) and Thymocytes. Relative SDF-1 mRNA levels normalized with GAPDH mRNA. The density of each band in each lane from three independent experiments was quantified by scanning densitometry and then expressed as mean $\pm \mathrm{SD}$.

in regenerating thymus of adult rat. Immunohistochemical staining for SDF-1 protein revealed that SDF-1-positive cells including thymocytes and epithelial cells were detected in paraseptal and corticomedullary regions of normal thymus (Fig. 2a and b). However, significantly increased expression of SDF-1 protein was observed in both cortext and medulla of regenerating thymus, especially at 3 days (Fig. $2 \mathrm{c}$ and d), 7 days (Fig. 2e and 2f), and even by 14 days after CY treatment (Fig. $2 \mathrm{~g}$ and $2 \mathrm{~h}$ ).

\section{Co-localization SDF-1 in ED-1-positive thymic macrophages}

Since the SDF-1-positive cells in regenerating thymic tissue were morphologically different to those in normal

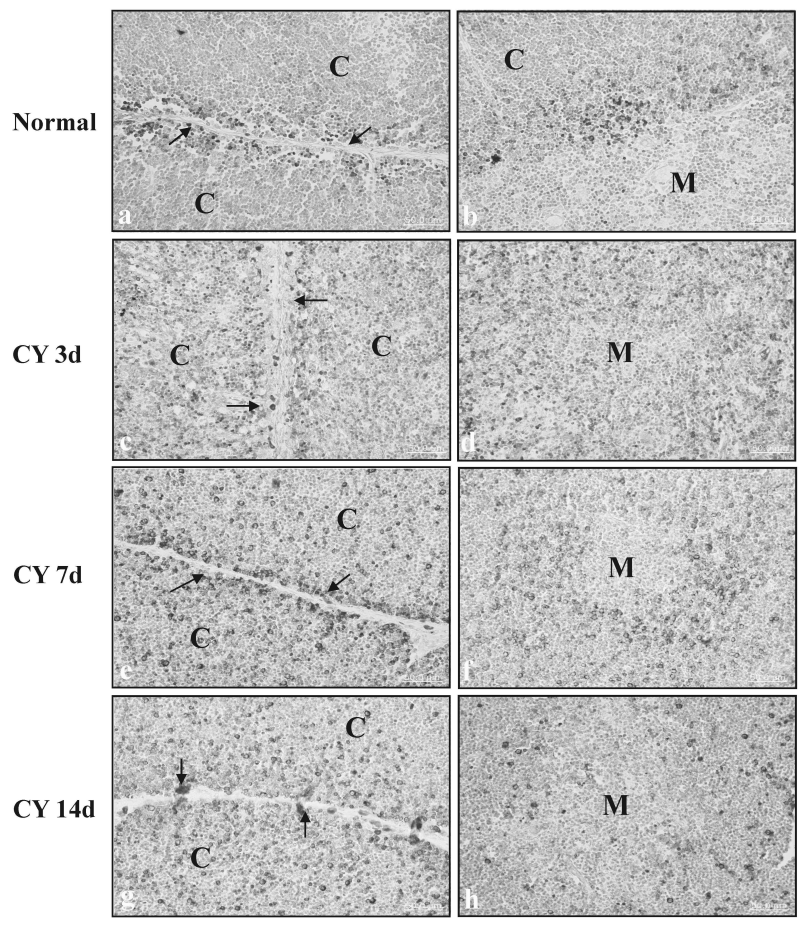

Fig. 2. Upregulation of SDF-1 protein expression during thymic regeneration. Immunohistochemical localization of SDF1 in the cortex $(\mathrm{C})$ and medulla $(\mathrm{M})$ of the normal thymus $(\mathrm{a}, \mathrm{b})$ and regenerating thymus $3(\mathrm{c}, \mathrm{d}), 7$ (e, f), and 14 $(g, h)$ days after cyclophosphamide treatment. In the normal rat thymus, the number of SDF-1 immunoreactive cells is increased during thymus regeneration. SDF-1 immunopositive cells are distributed not only in the medulla but also in the cortex, while these cells are scattered in the medulla and septum of the rat thymus. (X400)

thymus, we next examined the types of cells that are responsible for the SDF-1 upregulation during thymic regeneration. Double-immunohistochemistry for SDF-1 and ED-1 revealed that strong SDF-1 signals were detected in the thymic macrophage displaying immunoreactivity for ED-1 during thymic regeneration (Fig. 3).

\section{Discussion}

The present results showed for the first time that the levels of SDF-1 mRNA and protein were significantly up-regulated in thymic macrophages during thymic regeneration in adult rat. Among the SDF-1 genes analyzed, SDF-1 $\beta$ was the most interesting one because dramatic induction of SDF-1 $\beta$ expression was observed particularly in thymic stromal cells as well as in thymocytes during thymic regeneration (Fig. $1 \mathrm{~A}$ and B). SDF-1 protein expression confirmed by immunohiostochemistry was significantly elevated at 3 and 7 days 


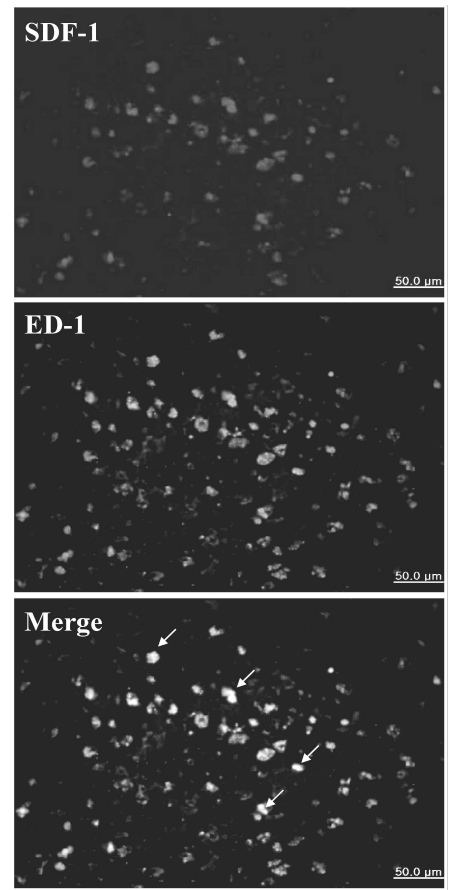

Fig. 3. Expression of SDF-1 in ED1-positive macrophages. Twocolor, double labeled immunofluorescent staining of SDF-1 (red) and ED1 (green) on thymic macrophages in rat thymus at 3 days after $C Y$ treatment. The individual recordings were used to create the merged images (yellow) showing simultaneous detection of SDF-1 and ED1. Cells expressing SDF-1 are ED1-positive macrophages (arrows). Magnification is 400X.

after CY treatment (Fig. 2). Most interestingly, cells immunolabeled for the SDF-1 protein were identified as macrophages by their co-expression of SDF-1 and ED1, as demonstrated by double-labeled immunofluorescence staining (Fig. 3).

The chemokine SDF-1 regulates many essential biological processes, including cardiac and neuronal development, stem cell survival, tumorigenesis and angiogenesis [2,13]. It was previous reported that SDF-1 binds only to CXCR4, and the signaling of SDF-1/CXCR4 plays an important and unique role in the regulation of stem/progenitor cell trafficking [7]. Recently, SDF-1 is also a highly efficacious chemotactic activity for immature thymocytes, $\mathrm{CD} 34^{+}$progenitor cells, lymphocytes and monocytes [3,5]. Therefore, it is likely that the upregulation of SDF-1 expression in regenerating thymus may contribute to thymic repair and remodeling through the trafficking of stem/progenitor cells.

SDF-1 also regulates processes essential to tumor metastasis and plays an important role in tumor vascularization [13]. In addition, the increased SDF-1 expression is associated with the recruitment of recipient-derived CXCR4- pos- itive cells in aortic allografts [15], and then SDF-1 promotes neointima formation in graft vasculopathy. We have previously demonstrated that reparative angiogenesis occurs dramatically during adult thymic regeneration that accompanies the up-regulation of VEGF gene expression, which is induced by NGF [12]. Although recent studies regarding important roles of angiogenesis in stimulating adult tissue regeneration have been published, they do not much address the molecular basis of the reparative angiogenesis during adult tissue repair/regeneration. In this study, the dramatic increase of SDF-1 mRNA and protein was found in the regenerating thymus, which is concurrent with the higher density of microvessels. Therefore, these observations suggest that SDF-1 highly induced in regenerating thymus may play an important role in the reparative angiogenesis during thymic regeneration.

Our previous studies have demonstrated that thymic macrophages are highly detected in thymus tissue during thymic regeneration following acute involution induced by $\mathrm{CY}$ treatment. In addition, SDF-1 is reported to be expressed in human thymus and to play a potential role in the elimination of apoptotic thymocytes in thymic tissue [20]. Thus, considering our present data that the levels of SDF-1are up-regulated in thymic macrophage during thymic regeneration, it is likely that SDF-1 may contribute to the recruitment and removal of damaged cells including thymocytes.

In summary, we have demonstrated for the first time that SDF-1 expression is highly increased in thymic macrophages during thymic regeneration. Our results indicate that thymic macrophages, through SDF-1 system, may participate in the stimulation and homing of endothelial cells and stem/progenitor cells, respectively, for thymus remodeling, which roles are very similar to those of tumor-associated macrophage, as well as in the removal of damaged or injured cells including thymocytes, suggesting that modulators of SDF-1 signaling might find usage as therapeutic regulators for the repair of acute, accidental, or age involution of adult thymus.

\section{Acknowledgement}

This work was supported for two years by Pusan National University Research Grant.

\section{References}

1. Anderson, G., N. C. Moore, J. J. Owen, and E. J. Jenkinson. 
1996. Cellular interactions in thymocyte development. Annu. Rev. Immunol. 14, 73-99.

2. Andreas, S. 2008. Chemokines in vascular dysfunction and remodeling. Arterioscler Thromb. Vasc. Biol. 28, 1950-1959.

3. Campbell, J. J., J. Pan, and E. C. Butcher. 1999. Cutting edge: developmental switches in chemokine responses during $\mathrm{T}$ cell maturation. J. Immunol. 163, 2353-2357.

4. Faas, S. F., J. L. Rothsteiin, B. L. Kreider, G. Rovera, and B. B. Knowles. 1993. Phenotypically diverse mouse thymic stromal cell lines which induce proliferation and differentiation of hematopoietic cells. Eur. J. Immunol. 23, 12011214.

5. Kim, C. H., L. M. Pelus, J. R. White, and H. E. Broxmeyer. 1998. Differential chemotactic behavior of developing T cells in response to thymic chemokines. Blood 91, 4434-4443.

6. Klein, R. S. and J. B. Rubin. 2004. Immune and nervous system CXCL12 and CXCR4: parallel roles in patterning and plasticity. Trends Immunol. 25, 306-314.

7. Kucia, M., K. Jankowski, R. Reca, M. Wysoczynski, L. Bandura, D. J. Allendorf, J. Zhang, J. Ratajczak, and M. Z. Ratajczak. 2004. CXCR4-SDF-1 signalling, locomotion, chemotaxis and adhesion. J. Mol. Histol. 35, 233-245.

8. Luster, A. D. 1998. Chemokines-chemotactic cytokines that mediate inflammation. New England Journal of Medicine 338, 436-445.

9. Milicevic, N. M., Z. Milicevic, O. Piletic, S. Mujovic, and V. Ninkov. 1984. Patterns of thymic regeneration in rats after single or divided doses of cyclophosphamide. J. Comp. Pathol. 94, 197-202.

10. Miller, J. P. 1961. Immunological function of the thymus. Lancet. 2, 748-749.

11. Nagasawa, T., H. Kikutani, and T. Kishimoto. 1994. Molecular cloning and structure of a pre-B-cell growth-stimulating factor. Proc. Natl. Acad Sci. 91, 2305-2309.

12. Park, H. J., M. N. Kim, J. G. Kim, Y. H. Bae, M. K. Bae,
H. J. Wee, T. W. Kim, B. S. Kim, J. B. Kim, S. K. Bae, and S. Yoon. 2007. Up-regulation of VEGF expression by NGF that enhances reparative angiogenesis during thymic regeneration in adult rat. BBA - Molecular Cell Research 1773, 1462-1472.

13. Ratajczak, M. Z., E. Zuba-Surma, M. Kucia, R. Reca, W. Wojakowski, and J. Ratajczak. 2006. The pleiotropic effects of the SDF-1-CXCR4 axis in organogenesis, regeneration and tumorigenesis. Leukemia 20, 1915-1924.

14. Ritter, M. A. and D. B. Palmer. 1999. The human thymic microenvironment: new approaches to functional analysis. Semin Immunol. 11, 13-21.

15. Sakihama, H., T. Masunaga, K., T. Hashimoto, M. Inobe, S. Todo, and T. Uede. 2004. Stromal cell-derived factor-1 and CXCR4 interaction is critical for development of transplant arteriosclerosis. Circulation 110, 2924-2930.

16. Shanker, A. 2004. Is thymus redundant after adulthood? Immunol. Lett. 91, 79-86.

17. Taub, D. D. and D. L. Longo. 2005. Insights into thymic aging and regeneration. Immunol. Rev. 205, 72-93.

18. Wald, O., O. Pappo, R. Safadi, M. Dagan-Berger, K. Beider, H. Wald, S. Franitza, I. Weiss, S. Avniel, P. Boaz, J. Hanna, G. Zamir, A. Eid, O. Mandelboim, U. Spengler, E. Galun, and A. Peled. 2004. Involvement of the CXCL12/CXCR4 pathway in the advanced liver disease that is associated with hepatitis C virus or hepatitis B virus. Eur. J. Immunol. 34, 1164-1174.

19. Yoon, S., Y. H. Yoo, B. S. Kim, and J. J. Kim. 1997. Ultrastructural alterations of the cortical epithelial cells of the rat thymus after cyclophosphamide treatment. Histol. Histopathol. 12, 401-413.

20. Zaitseva, M., T. Kawamura, R. Loomis, H. Goldstein, A. Blauvelt, and H. Golding. 2002. Stromal-derived factor 1 expression in the human thymus. J. Immunol. 15, 2609-2617.

\title{
초록 : 흰쥐 가슴샘 재생과정 동안 대식세포에서 SDF-1의 발현증가
}

\author{
${\text { 박현주 }{ }^{1,4} \cdot \text { 김종갑 }}^{24,5} \cdot$ 윤식 ${ }^{3,45} \cdot$ 배문경 $\cdot$ 배수경 $2,4,5 *$ \\ ( ${ }^{1}$ 부산대학교 치의학전문대학원 구강생리학교실, ${ }^{2}$ 부산대학교 의학전문대학원 생리학교실, ${ }^{3}$ 부산대학교 의학 \\ 전문대학원 해부학교실, ${ }^{4}$ 부산대학교 허혈조직재생연구센터, ${ }^{5}$ 부산대학교 BK21 고급 의료인력 양성사업단)
}

성체흰쥐의 경우 항암제인 싸이클로포스파마이드(CY)처리로 퇴축된 가슴샘은 2 주 후에 정상조직으로 재생된다. 가슴샘 발생과정에서 이미 알려진 SDF-1 신호전달의 중요성과는 달리 성체의 가슴샘 재생과정에서 그 역할에 관해서는 알려진 바 전혀 없다. 본 연구의 목적은 발생중인 가슴샘에서 발현이 증가된다고 이미 알려져 있는 SDF-1 이 성체의 가슴샘재생과정에서 어떤 발현 양상을 보이는지를 조사하는 것이다. 본 연구에서는 사이클로포스파마이 드(cyclophosphamide: CY)를 투여하여 가슴샘의 급성 퇴축을 유발시킨 후, 가슴샘 재생과정동안 SDF-1의 발현 특성을 면역조직화학, 이중면역염색 형광법, 역전사 중합효소 연쇄반응법을 이용하여 조사하였다. 그 결과, SDF-1은 가슴샘의 급성 퇴축 이후 7 일째 되는 시기에 mRNA와 단백질의 양이 급격히 증가하였으며, 이중면역염색 형광법을 통해 큰포식 세포와 위치적 분포가 일치함을 확인하였다. 따라서, 본 연구 결과들을 통해 SDF-1은 가슴샘의 급성 퇴축 초기 과정에서 나타나는 손상된 세포를 처리하는 큰포식 세포의 기능 조절에 관여할 것으로 생각된다. 